Review Article

\title{
COVID-19 in China, Italy and the United States of America: a short review
}

\author{
COVID-19 em China, Itália e Estados Unidos da América: uma breve revisão
}

\author{
Amanda Ribeiro Rangel'1, Luísa Macambira Noronha', Gabriel Cavalcante Lima Chagas ${ }^{1}$, \\ Gdayllon Cavalcante Meneses², Geraldo Bezerra da Silva Júnior³, \\ Roberto da Justa Pires Neto ${ }^{4}$, Elizabeth de Francesco Daher ${ }^{1}$
}

Rangel AR, Noronha LM, Chagas GCL, Meneses GC, Silva Júnior GB, Pires Neto RJ, Daher EF. COVID-19 in China, Italy and the United States of America: a short review / COVID-19 em China, Itália e Estados Unidos da América: uma breve revisão. Rev Med (São Paulo). 2021 March-April;100(2):162-70.

\begin{abstract}
In December 2019, a novel coronavirus was discovered and associated with a cluster of pneumonia of unknown cause in China. SARS-CoV-2 rapidly spread and is now characterized as a pandemic. The objective of this study is to discuss COVID-19 general features, including epidemiology, transmission, control measures, virology, diagnosis, clinical characteristics and radiological and laboratory results. In this context, literature was assessed to compare the three most affected countries in Asia, Europe and Americas on March 31, 2020. The main form of transmission is human-to-human by respiratory secretions, and studies indicated substantial involvement of asymptomatic patients in this process. COVID-19 patients are predominantly men and may present multiple symptoms, especially fever and cough. Arterial hypertension and diabetes mellitus were the most common comorbidities. Worse outcomes are associated with increased age, comorbidities, and complications. Abnormalities in computed tomography of the chest are frequent, with pulmonary ground-glass opacity and bilateral patchy shadowing as the most common patterns, but a significant percentage of patients do not present any findings at time of admission. Laboratory results often present lymphocytopenia, increased neutrophils and platelet counts, erythrocyte sedimentation rate, lactate dehydrogenase, C-reactive protein, ferritin, total bilirubin, aspartate aminotransferase, alanine aminotransferase, creatinine, creatine phosphokinase, myoglobin, glucose and cytokines. Although radiological findings and laboratory results presented similarities in China, Italy and USA, case-fatality rates can be conflicting suggesting, therefore, the need for studies according to each region.
\end{abstract}

Keywords: Coronavirus infections; Epidemiology; Signs and symptoms; Pandemics.
RESUMO: Em dezembro de 2019, um novo coronavírus foi identificado e associado à ocorrência de pneumonia de causa desconhecida na China. SARS-CoV-2 rapidamente disseminouse, e, atualmente, a COVID-19 é classificada como pandemia. $\mathrm{O}$ objetivo desse estudo consiste em discutir as características gerais da COVID-19, incluindo a epidemiologia, transmissão, medidas de controle, virologia, diagnóstico, apresentações clínicas e achados radiológicos e laboratoriais. Nesse contexto, foram consultados artigos publicados em base de dados com a finalidade de comparação entre países mais afetados na Ásia, Europa e América até 31 de março de 2020. A principal forma de transmissão ocorre entre humanos por secreções respiratórias, e estudos indicam um substancial envolvimento de pacientes assintomáticos nesse processo. Pacientes com COVID-19 são predominantemente homens e podem apresentar inúmeros sintomas, especialmente febre e tosse. Hipertensão arterial e diabetes mellitus foram as comorbidades mais comuns. Pior prognóstico está associados a aumento da idade, comorbidades e complicações. Anormalidades na tomografia computadorizada de tórax são frequentes, sendo opacidades em vidro fosco e infiltrados bilaterais os padrões pulmonares mais comuns, contudo porcentagem significativa dos pacientes não apresenta alterações na admissão. Exames laboratoriais normalmente apresentam linfocitopenia, aumento de contagem de neutrófilos e plaquetas, velocidade de hemossedimentação, lactato desidrogenase, proteína $\mathrm{C}$ reativa, ferritina, bilirrubina total, aspartato aminotransferase, alanina aminotransferase, creatinina, creatina fosfoquinase, mioglobina, glicose e citocinas. Apesar dos achados radiológicos e laboratoriais apresentarem similaridades na China, Itália e EUA, as taxas de mortalidade podem ser conflitantes, sugerindo, portanto, a necessidade de estudos de acordo com cada região..

Palavras-chave: Infecções por Coronavírus; Epidemiologia; Sinais e sintomas; Pandemia.

1. Post-Graduation Program in Medical Sciences, Department of Internal Medicine, Federal University of Ceará, Fortaleza, CE. ORCID: Rangel AR - https://orcid.org/0000-0001-8116-9251; Noronha LM - https://orcid.org/0000-0002-0736-8225; Chagas GCLC - https://orcid.org/0000-0002-73989070; Daher EF - https://orcid.org/0000-0003-4189-1738. E-mails: amandaribeiror@hotmail.com; luisamacambira@gmail.com; gabrielchagas.gc@ gmail.com; ef.daher@yahoo.com.br.

2. Department of Clinical and Toxicological Analysis, School of Pharmacy, Federal University of Ceará, Fortaleza, CE. https://orcid.org/0000-00020160-5728. E-mail: gdayllon@yahoo.com.br.

3. Public Health and Medical Sciences Graduate Programs, School of Medicine, Health Sciences Center, University of Fortaleza. Fortaleza, CE. https:// orcid.org/0000-0002-8971-0994. E-mail: geraldobezerrajr@yahoo.com.br.

4. Post-Graduation Program in Public Health, Department of Community Health, Federal University of Ceará, Fortaleza, CE. https://orcid.org/00000003-0291-9523.robertojusta@gmail.com.

Correspondence: Amanda R. Rangel. Av. Santos Dumont, 3210, Apt. 308 A. Fortaleza, CE, BR.. CEP: 60150-162. E-mail: amandaribeiror@hotmail.com. 


\section{INTRODUCTION}

Tn December 2019, there were several reports about patients with acute respiratory infection of unknown cause in hospitals of Wuhan, China ${ }^{1-3}$. The pathogen was identified as a new coronavirus and first named as 2019-nCoV ${ }^{1,2}$. In February 2020, the Coronavirus Study Group (CSG) of the International Committee officially named the virus as Severe Acute Respiratory Syndrome Coronavirus 2 (SARS-CoV-2) ${ }^{1}$. The coronavirus-related disease was named COVID-19 by the World Health Organization (WHO $)^{4}$.

In this review article, we intend to discuss COVID-19 general features, including epidemiology, transmission, control measures, virology, diagnosis, clinical characteristics and radiological and laboratory results. Thus, literature was assessed to summarize similarities and differences between the three most affected countries in Asia, Europe and Americas on March 31, 2020, according to the WHO $71^{\text {st }}$ report $^{5}$.

\section{DISCUSSION}

\section{Epidemiology}

The first cases of the disease were linked to a seafood market in Wuhan, province of Hubei, China, in which the majority of the patients had been there or stayed nearby before getting sick ${ }^{1,2}$, suggesting that the origin of the virus was from the market; although, this hypothesis was not confirmed so far ${ }^{1}$.

The number of cases rapidly increased and spread to other locations inside and outside China ${ }^{2}$. On January 30, 2020, WHO declared the COVID-19 outbreak a public health emergency of international concern (PHEIC) ${ }^{6}$, and on March 11, 2020 characterized the disease as a pandemic ${ }^{7}$.

According to data of WHO on May 5, 2020, COVID-19 was present in every continent, except in Antarctic, with 3,525,116 confirmed cases and 243,540 deaths ${ }^{8}$. The United States of America (USA) was the country with more confirmed cases worldwide, accounting nearly $78 \%$ of the cases in the Americas; when comparing continents, Europe had the higher number, with almost $44 \%$ of the total amount ${ }^{8}$.

\section{Transmission}

The main form of transmission of COVID-19 is human-to-human by respiratory secretions, with droplets or contact ${ }^{9,10}$. Wang et al. ${ }^{11}$ evaluated the presence of SARS-CoV-2 in other sites, including nasal samples, sputum, pharyngeal swabs, bronchoalveolar lavage fluid, fibrobronchoscope brush biopsy, blood, urine, and feces. In this analysis, besides urine samples, all the other sites had a percentage of positive results (Table 1).
Table 1: Study of Wang et al. evaluating the presence of SARSCoV-2 in 1070 specimens of 205 patients with COVID-19

\begin{tabular}{lc}
\hline Specimens & Presence of SARS-CoV-2 \\
\hline Blood & Positive \\
Bronchoalveolar lavage & Positive \\
fluid & \\
Feces & Positive with live virus \\
Fibrobronchoscope brush & Positive \\
biopsy & \\
Nasal samples & Positive \\
Pharyngeal swabs & Positive \\
Sputum & Positive \\
Urine & Negative \\
\hline
\end{tabular}

Other study identified SARS-CoV-2 in gastrointestinal tract, saliva, and urine, suggesting potential routes of transmission ${ }^{12}$. COVID-19 may also have a systemic component, supported by the presence of viral RNA in the blood of some patients ${ }^{10,11}$. These findings endorse the possibility that testing of specimens from multiple locations may reduce the risk of false-negative results $^{11}$. However, there is not enough data for decisive conclusions, reaffirming that more studies are needed to fully understand the forms of transmission of the novel coronavirus.

Moreover, the period during the illness that an infected patient can transmit the disease is uncertain, but it can start before the development of symptoms ${ }^{10,13}$.

Arons et al. ${ }^{14}$ evaluated an outbreak of COVID-19 in a nursing facility in the USA, where $56 \%$ of patients with SARS-CoV-2 infection reported no symptoms at the moment of the test. Of those asymptomatic patients, $86 \%$ developed symptoms later, being classified as presymptomatic patients. It is suggested that asymptomatic and presymptomatic patients had a contribution to the extent of the spread of COVID-19 in this facility, with a potential of viral shedding.

On top of that, studies have shown high viral load in the beginning of the symptomatic phase, suggesting more risk of transmission in this stage ${ }^{15}$. Similar values were found in symptomatic and asymptomatic patients, reasserting the transmission of the disease by asymptomatic patients ${ }^{15}$. Therefore, evidence of SARS-CoV-2 transmission from presymptomatic individuals has been shown in other investigations ${ }^{14,16-18}$.

\section{Control measures}

WHO suggested some measures to control the transmission of the virus, such as rapid case identification, rapid testing and isolation of cases, comprehensive contact 
tracing and quarantine of contacts ${ }^{19}$. These actions may reduce the spread of COVID-19, avoiding the health systems overload and allowing them to efficiently take care of the demand.

Several countries, which had a large number of community transmission, implemented other measures to contain the outbreak, for example, widespread populationlevel physical distancing measures and movement restrictions ${ }^{19}$. However, these actions significantly impact the society, causing innumerous psychological consequences ${ }^{20,21}$ and negative impacts in economy ${ }^{19,22}$. Moreover, some groups can be more affected, such as people in poverty, immigrants, refugees and those who live in overcrowded and under-resourced settings ${ }^{19,23}$.

\section{Virology}

SARS-CoV-2 is a single-stranded positive RNA virus that belong to the Coronaviridae family, which can infect humans and animals, causing respiratory, gastrointestinal diseases, and other affections ${ }^{2,24}$.

Besides the recently discovered SARS-CoV-2, there are six known coronavirus that infect humans: HCoVsNL63, HCoVs-229E, HCoVs-OC43, HCoVs-HKU1, severe acute respiratory syndrome coronavirus (SARS$\mathrm{CoV}$ ) and Middle East respiratory syndrome coronavirus (MERS-CoV) ${ }^{1-3,24}$. The majority of them causes mild diseases, but two were responsible for thousands of deaths in the twenty first century, SARS-CoV, which caused severe acute respiratory syndrome outbreak in 2002, especially in Asia, and the MERS-CoV, which caused Middle East respiratory syndrome outbreak in $2012^{3,24,25}$.

SARS-CoV-2 is a beta coronavirus, as SARS-CoV and MERS-CoV, but it is considered to be more infectious than them, because it has a higher transmissibility ${ }^{9}$. Studies demonstrated that SARS-CoV-2 uses the same receptor as SARS-CoV to enter host's cells, the angiotensin-converting enzyme 2 (ACE2), different from MERS-CoV, which uses the dipeptidyl peptidase 4 (DPP4) $)^{1,26-28}$ (Table 2).

Table 2 - Comparison between SARS-CoV-2, SARS-CoV and MERS-CoV.

\begin{tabular}{lccc}
\hline & MERS-CoV & SARS-CoV & SARS-CoV-2 \\
\hline Similarity with SARS-CoV-2 & $51,8 \%$ & $79,0 \%$ & - \\
Target receptor in human's cells & DPP4 & ACE2 & ACE2 \\
\hline
\end{tabular}

ACE2: angiotensin-converting enzyme 2; DPP4: dipeptidyl peptidase 4

Furthermore, many studies were made to elucidate the distribution of ACE2 through the body, aiming to identify which cells might represent a way of entrance for SARS-CoV-2 ${ }^{4,29}$. High expression of this receptor was found in type II alveolar cells (AT2) of the lung, upper esophagus and stratified epithelial cells, absorptive enterocytes from ileum and colon, cholangiocytes, myocardial cells, kidney proximal tubule cells, and bladder urothelial cells ${ }^{4,29}$. These findings support the idea that other organs might be at risk of infection by the SARS-CoV-2.

Genetically, SARS-CoV-2 is more similar to coronavirus of bat origin: bat-SL-CoVZC45 and bat-SLCoVZXC21 $1^{4,25}$. In fact, in nucleotide identity, it has $79.0 \%$ of similarity to SARS-CoV, 51.8\% with MERS-CoV, and over $90 \%$ to a bat coronavirus ${ }^{24}$. These findings suggest that SARS-CoV-2 might be originated from bats, which are a natural reservoir of many coronavirus ${ }^{1,28}$, and could be transmitted to human directly from them or by an unknown intermediate $^{1,2}$.

\section{Evaluation and Diagnosis}

As a new disease that presents flu-like symptoms, which lead to many possible differential diagnoses, the suspicion can occur in three possible scenarios ${ }^{30}$. The first is a person presenting acute respiratory disease, with fever and symptoms of respiratory disease, such as shortness of breath and cough, and with a history of travel to or residence in areas with reported community transmission within 14 days of the beginning of symptoms ${ }^{30}$. The second is a symptomatic individual presenting acute respiratory illness with a history of contact with a suspect or confirmed case within 14 days of the beginning of symptoms ${ }^{30}$. The third is a patient presenting severe respiratory illness, with fever and symptoms of respiratory disease, requiring hospitalization and without other diagnosis that explain all the findings ${ }^{30}$. These cases are labeled as suspect and require laboratory confirmation of SARS-CoV-2 infection.

The confirmed diagnosis is made by nucleic acid amplification tests (NAAT), such as real-time reversetranscription polymerase chain reaction (rRT-PCR), based in the detection of parts of the viral $\mathrm{RNA}^{31}$. The chosen samples are respiratory secretions, especially from the upper respiratory tract for initial testing ${ }^{31,32}$. The Centers for Disease Control and Prevention (CDC) of the USA recommends nasopharyngeal, oropharyngeal specimen, nasal swab specimen, nasopharyngeal wash/aspirate or nasal wash/aspirate specimen ${ }^{32}$. The test of lower respiratory tract also can be done $\mathrm{e}^{31,32}$.

As a matter of fact, because COVID-19 is a new disease, most laboratories were not prepared to deal with the high number of cases that need to be evaluated ${ }^{33}$. So, in order to test the patients that are more likely to have the disease, some criteria can be established, such as prioritize 
individuals with more severe illness and contact with confirmed cases ${ }^{33,34}$.

\section{Clinical characteristics}

First, in January 2020, Huang et al. ${ }^{35}$ reported the main clinical features of 41 SARS-CoV-2 infected patients in Wuhan, observing male prevalence $(73 \%)$ and a median age of 49 years (IQR, 41-58). Subsequent studies conducted in the same hospital presented similar features ${ }^{36,37}$.

In February 2020, also at the epicenter of the COVID-19 pandemic, 138 patients presented similar results, with a prevalence of men $(54.3 \%)$ and a median age of 56 years (IQR, 42-68) $)^{38}$.

Guan et al. ${ }^{12}$, in a larger study, with data regarding 1099 patients from 30 provinces in China, also showed a preponderance of men $(58 \%)$ and a median age of 47 years (35-58).

In Italy, a retrospective case series of 1591 patients with COVID-19 referred for Intensive Care Unit (ICU) admission, where $82 \%$ were male and the median age was elevated [63 years (IQR, 56-70) years] $]^{39}$, which is possibly associated with demographic characteristics in this country.
Similarly, in the USA, a multicenter retrospective analysis in Seattle also presented that $63 \%$ of patients were men and had a mean age of 64 years ${ }^{40}$.

\section{Clinical Features}

The median time from onset of symptoms to first hospital admission was seven days ${ }^{35,38}$. Almost $90 \%$ of patients infected with SARS-CoV-2 presented multiple symptoms ${ }^{37}$. Initial studies about clinical manifestations of the disease included fever as the most common symptom (83-98.6\%), followed by cough (59.4-82\%) and fatigue/ myalgia (38.1\%-69.6\%), resembling SARS-CoV and MERS-CoV infections ${ }^{12,35-37}$.

Guan et al. ${ }^{12}$, however, suggested that fever was not the hallmark of COVID-19 onset, since it was present in only $43.8 \%$ of the patients at the time of admission, but $88.7 \%$ of the patients developed during hospitalization.

Gastrointestinal symptoms were uncommon and included nausea and vomiting (1-5\%), and diarrhoea (2-3.8\%). When analyzing only critically ill patients, the prevalence of those symptoms increased to $10.1 \%{ }^{38}$ (Table 3).

Table 3 - Summary of Clinical Manifestations in COVID-19 patients in China, Italy and United States of America

\begin{tabular}{lcccccc}
\hline & Huang et al. & Yang et al. & Chen et al. & Wang et al. & Guan et al. & Arentz et al. \\
\hline & $\mathrm{n}=41$ & $\mathrm{n}=52$ & $\mathrm{n}=99$ & $\mathrm{n}=138$ & $\mathrm{n}=1099$ & $\mathrm{n}=21$ \\
\hline Fever & $98.6 \%$ & $98 \%$ & $83 \%$ & $98 \%$ & $43.8 \%$ & $52.4 \%$ \\
Cough & $76 \%$ & $77 \%$ & $82 \%$ & $59.4 \%$ & $67.8 \%$ & $47.6 \%$ \\
Fatigue & $44 \%$ & - & - & $69.6 \%$ & $38.1 \%$ & - \\
Diarrhoea & $3 \%$ & - & $2 \%$ & $10.1 \%$ & $3.8 \%$ & - \\
Nausea/Vomiting & $5 \%$ & $4 \%$ & $1 \%$ & $10.1 \%$ & $5 \%$ & - \\
\hline
\end{tabular}

\section{Comorbidities}

The presence of any comorbidity varied from $23.7 \%$ to $46.7 \%$ according to studies in China ${ }^{12,38}$. Arterial hypertension, cardiovascular disease, and diabetes mellitus were the most common comorbidities associated with COVID-197,12,35-38,40-42.
Furthermore, studies showed a higher prevalence of underlying diseases in Italy (86\%) and USA (37.6$86 \%)^{39,41,43}$. Moreover, an analysis of critically ill patients in Washington, USA, reported that almost half of the patients had chronic kidney disease (CKD) (47.6\%) and congestive heart failure $(42.9 \%)^{41}$ (Table 4$)$.

Table 4 - Summary of Comorbidities in COVID-19 Patients in China, Italy and United States of America

\begin{tabular}{|c|c|c|c|c|c|c|c|c|}
\hline & Huang et al. & Yang et al. & Chen et al. & Wang et al. & Guan et al. & Onder et al. & Grasselli et al. & Arentz et al. \\
\hline & $\mathrm{n}=41$ & $\mathrm{n}=52$ & $\mathrm{n}=99$ & $\mathrm{n}=138$ & $\mathrm{n}=1099$ & $\mathrm{n}=355$ & $\mathrm{n}=1591$ & $\mathrm{n}=21$ \\
\hline Coexisting disorder & $32 \%$ & $40 \%$ & $51 \%$ & $46.4 \%$ & $23.7 \%$ & $99.2 \%-$ & $68 \%$ & $86 \%$ \\
\hline Arterial hypertension & $15 \%$ & - & - & $31.2 \%$ & $15 \%$ & - & $49 \%$ & - \\
\hline Diabetes mellitus & $20 \%$ & $17 \%$ & $12 \%$ & $10.1 \%$ & $7.4 \%$ & $35.5 \%$ & $17 \%$ & $33.3 \%$ \\
\hline Cardiovascular disease $\mathrm{e}^{\mathrm{a}, \mathrm{b}, \mathrm{c}}$ & $15 \%$ & $10 \%$ & $40 \%$ & $14.5 \%$ & $2.5 \%$ & $54,5 \%$ - & $21 \%$ & $42.9 \%$ \\
\hline COPD & $2 \%$ & $8 \%$ & - & $2.9 \%$ & $1.1 \%$ & - & $4 \%$ & $33.3 \%$ \\
\hline Malignancy & $2 \%$ & $4 \%$ & $1 \%$ & $7.2 \%$ & $0.9 \%$ & $20.3 \%$ & $8 \%$ & - \\
\hline Cerebrovascular disease & - & $13.5 \%$ & - & $5.1 \%$ & $1.4 \%$ & $9.6 \%-$ & - & - \\
\hline CKD & - & - & - & $2.9 \%$ & $0.7 \%$ & - & $3 \%$ & $47.6 \%$ \\
\hline
\end{tabular}

COPD: Chronic obstructive pulmonary disease; CKD: Chronic kidney disease. ${ }^{\text {a }}$ Cardiovascular and cerebrovascular diseases grouped (Chen et al.). ${ }^{b}$ Cardiovascular disease included atrial fibrillation and ischemic heart disease (Onder et al.). ${ }^{\mathrm{C}}$ Congestive heart failure (Arentz et al.). 


\section{Complications}

Acute respiratory distress syndrome (ARDS) was the main complication for COVID-19, suggesting a stronger component of respiratory affection, according to studies from Wuhan, China ${ }^{12,35-38}$. Additionally, the prevalence of acute cardiac injury, acute kidney injury (AKI), and liver disfunction revealed that other organ systems were also compromised $^{12,35-38,41}$.

Analysis of 1099 COVID-19 patients across China revealed that ARDS and AKI only occurred in $3.5 \%$ and $0.5 \%$ of cases, respectively ${ }^{12}$. Differently, the analysis of severe COVID-19 patients presented an increased prevalence of ARDS (81\%), AKI (29\%), and a higher demand for medical ventilation (71\%) and renal replacement therapy (RRT) $(17 \%)^{36}$.

In Washington, the first description of COVID-19 critically ill patients in the USA, revealed that $95.2 \%$ of all the patients presented ARDS and that $71 \%$ of them required mechanical ventilation ${ }^{41}$. Grasselli et al. ${ }^{39}$ presented compatible outcomes in Italy, revealing that $99 \%$ (95\% CI, $98 \%-99 \%$ ) of ICU patients needed respiratory support, including $88 \%$ (95\% CI, 87\%-90\%) who received invasive mechanical ventilation(Table 5).

Table 5 - Summary of Complications in COVID-19 Patients in China, Italy and United States of America

\begin{tabular}{|c|c|c|c|c|c|c|c|}
\hline & Huang et al. & Yang et al. & Chen et al. & Wang et al. & Guan et al. & Arentz et al. & Grasseli et al. \\
\hline & $\mathrm{n}=41$ & $\mathrm{n}=52$ & $\mathrm{n}=99$ & $\mathrm{n}=138$ & $\mathrm{n}=1099$ & $\mathrm{n}=21$ & $\mathrm{n}=1591$ \\
\hline Pneumonia & $100 \%$ & - & - & - & $91.1 \%$ & - & - \\
\hline ARDS & $29 \%$ & $67 \%$ & $17 \%$ & $19.6 \%$ & $3.4 \%$ & $95.2 \%$ & - \\
\hline Invasive mechanical ventilation & $10 \%$ & $71 \%$ & $4 \%$ & $47.2 \%$ & $6.1 \%$ & $71 \%$ & $88 \%$ \\
\hline $\begin{array}{l}\text { Acute cardiac injury; } \\
\text { Cardiomyopathy }\end{array}$ & $12 \%$ & $23 \%$ & - & $7.2 \%$ & - & $33.3 \%$ & - \\
\hline AKI & $7 \%$ & $29 \%$ & $3 \%$ & $3.6 \%$ & $0.5 \%$ & $19.1 \%$ & - \\
\hline RRT & $7 \%$ & $17 \%$ & $9 \%$ & - & $0.8 \%$ & - & - \\
\hline Liver dysfunction & - & $29 \%$ & - & - & - & $14.3 \%$ & - \\
\hline
\end{tabular}

ARDS: Acute respiratory distress syndrome; AKI: Acute kidney injury; RRT: renal replacement therapy.

${ }^{a}$ Defined as evidence of a globally decreased left ventricular systolic function on transthoracic echocardiogram in addition to clinical signs of cardiogenic shock, an elevation in level of creatinine kinase or troponin I, or a decrease in central venous oxygen saturation (Arentz et al.)

\section{Risk factors for ICU admission}

Initially, only the presence of complications was statically significant for admission to $\mathrm{ICU}^{35}$. Subsequent studies demonstrated that the elderly and patients with any underlying disease were prone to poor clinical outcomes and increased risk of death, correlating these findings with a weaker immune response and cytokine storm in those patients $^{36-38}$.

Patients in ICU in Wuhan, China, were older [median age 66 years (IQR, 57-78) vs 51 years (IQR, 37-62); $\mathrm{p}<0.001$ ] and more likely to have complications and chronic illness $(72.2 \%$ vs $46.6 \%$; $<<0.001)$, including arterial hypertension ( $58.3 \%$ vs $21.6 \%$ ), diabetes mellitus (22.2\% vs $5.9 \%)$, cardiovascular disease ( $25.0 \%$ vs $10.8 \%)$, and cerebrovascular disease $(16.7 \%$ vs $1.0 \%)$ than nonICU patients ${ }^{38}$. COVID-19 in Wuhan, China, also tended to progress faster in the elderly, with shorter days between the occurrence of the first symptoms until death among people aged 70 years or more than those aged less than 70 years $(11.5 \text { vs } 20 \text { days, } p=0.033)^{44}$.

In agreement, an Italian cohort referred that $68 \%$ of the ICU patients had at least one comorbidity. However, the median age of severe patients was 63 (IQR, 56-70) years, the same as the median age of all positive Italian cases with COVID-19, suggesting that older age alone is not a risk factor for admission to the $\mathrm{ICU}^{39}$. On this basis, USA studies also referred a higher percentage of chronic illness among patients requiring $\mathrm{ICU}^{45}$, and an increased risk of poor outcomes among people aged $\geq 85$ years $^{42,43}$.

In Wuhan, China, non-survivors were mostly men (66\%), and $50 \%$ of them had chronic medical illness. Even more, these patients were more likely to receive mechanical ventilation ( $94 \%$ vs $35 \%$ ), either invasively or non-invasively, when compared with survivors ${ }^{36}$. Likewise, in Italy, non-survivors were predominantly men (70\%) and $48.5 \%$ of them had 3 or more underlying diseases ${ }^{34}$.

Comparison of fatalities between China and Italy initially evidenced equivalent case fatality rates $(2.3)^{46}$. Furthermore, the current difference between the overall case-fatality rate in Italy (7.2) and China (2.3) was suggested to be related with: demographic differences between those countries, including older patients with more comorbidities in Italy; the classification method of COVID-19-related deaths and different strategies for SARS-CoV-2 infection diagnosis ${ }^{34}$. In this context, Lippi et al. ${ }^{13}$ also suggested that the higher risk of death in Italy could be associated to the variable frequency of risk factors 
across different populations.

\section{Radiological Findings}

Huang et al. ${ }^{35}$ revealed that all patients showed abnormalities in computed tomography (CT) of the chest at admission and 98\% had bilateral pulmonary involvement, findings consistent with posterior studies also realized in Wuhan, China ${ }^{36-38}$.

A larger study in China including 1099 patients revealed no $\mathrm{CT}$ abnormalities at the time of admission in $13.8 \%$ of them and absence of radiologic or CT abnormalities in $17.9 \%$ of those with no severe disease. Pulmonary ground-glass opacity $(56.4 \%)$ and bilateral patchy shadowing $(51.8 \%)$ were the most common patterns ${ }^{12}$.

An abnormal chest radiograph was observed in 20 patients (95\%) at admission in ICU patients in Washington, USA at admission. The most common findings on initial radiograph were bilateral reticular nodular opacities (11 patients [52\%]) and ground-glass opacities (10 [48\%]). By 72 hours, 18 patients $(86 \%)$ had bilateral reticular nodular opacities and 14 (67\%) had evidence of groundglass opacities ${ }^{41}$.

In another retrospective study in Seattle, USA, almost equal results were observed. A chest radiograph was obtained in 23 patients $(96 \%)$ on ICU admission, and all the radiographs showed bilateral pulmonary opacities ${ }^{40}$.

\section{Laboratory Results}

In China, lymphocytopenia (lymphocyte count $<1.0 \times 10^{9} / \mathrm{L}$ ) was present in $35 \%-83.2 \%$ of the patients ${ }^{1,12,35-38}$. In retrospective studies with critically ill adult patients, low lymphocyte count occurred in more than $80 \%$ of them, a feature that is also prominent in SARS-CoV and MERS$\mathrm{CoV}$ infection ${ }^{36}$. However, in other studies, only $35 \%$ of non-severe COVID-19 patients had lymphocytopenia, suggesting that a lower lymphocyte count reflects the severity of SARS-CoV-2 infection ${ }^{37}$. In the USA, Bhatraju et al. ${ }^{40}$ exhibited common lymphocytopenia (75\%) among patients admitted to ICU, and Arendtz et al. ${ }^{41}$ presented that $67 \%$ of the ICU admitted patients had absolute lymphocyte count of less than 1000 cells $/ \mu \mathrm{L}$.

In China, the blood counts of patients on admission showed that $25 \%-33.7 \%$ had leukopenia (white blood cell count $\left.<4.0 \times 10^{9} / \mathrm{L}\right)^{12,35}$. In USA, Arentz et al. ${ }^{41}$ presented that $67 \%$ of the patients had white blood cell count in the normal range.

Lactate dehydrogenase was increased in 39.9\% to $75 \%$ of the patients ${ }^{37,38}$. D-dimer, C-reactive protein, aspartate aminotransferase, and interleukin (IL)-6 were also elevated in plasma $(36 \%, 86 \%, 34 \%, 52 \% \text {, respectively })^{37}$. Other findings included decreased albumin and increased levels of neutrophils, platelets, erythrocyte sedimentation rate, total bilirubin, alanine aminotransferase, ferritin, creatinine, creatine kinase, myoglobin and glucose $\mathrm{e}^{12,35,37}$.

There were also differences in laboratory findings between patients that required ICU and those who not. ICU patients presented higher white blood cell and neutrophil counts, as well as higher levels of D-dimer and creatine kinase than those not admitted to the $\mathrm{ICU}^{38}$.

\section{Immune response and Cytokine Storm}

The spread of SARS-CoV-2 particles through the respiratory mucosa infects other cells and triggers immune responses, inducing a systemic cytokine storm that generates changes in peripheral white blood cells or immune cells. At the same time that the immunological response is vital for the control and resolution of infections, it can also lead to immunopathogenesis when out of control $^{1,38}$.

COVID-19 patients had increased levels of plasma cytokines and chemokines, including IL-1, IL-2, IL-4, IL-7, IL-10, IL-12, IL-13, IL-17, granulocyte colony-stimulating factor (GCSF), macrophage colony-stimulating factor (MCSF), 10kD interferon-gamma-induced protein (IP-10), monocyte chemoattractant protein-1(MCP-1), macrophage inflammatory protein 1- $\alpha$ (MIP-1 $\alpha)$, hepatocyte growth factor (HGF), interferon gamma (IFN- $\gamma$ ) and tumor necrosis factor $\alpha(\mathrm{TNF}-\alpha)^{1}$.

Cytokines in plasma were elevated in individuals infected by SARS-CoV-2 that required ICU admission, suggesting an association with COVID-19 severity. Neutrophil count, D-dimer, blood urea nitrogen (BUN), and creatinine levels were significantly higher in severe patients, while the lymphocyte counts were decreased. Inflammatory factors IL-2, IL-6, IL-7, IL-10, and TNF- $\alpha$ were also elevated ${ }^{1,35}$.

Lymphocytopenia was higher in ICU patients $(85 \%$ vs $54 \%, \mathrm{p}<0.045)$ when compared with non-ICU patients ${ }^{35}$. Some studies suggested that a substantial decrease in the total number of lymphocytes indicates that coronavirus induces the consume of many immune cells and inhibition of the body's cellular immune function. Thus, damage to $\mathrm{T}$ lymphocytes might be an important factor leading to exacerbations of patients ${ }^{37}$.

Moreover, strengthening of immune support could be beneficial to populations with low immune function with COVID-19, such as the elderly, diabetics, people with long-term use of immunosuppressive agents, and pregnant women ${ }^{37}$.

\section{CONCLUSION}

SARS-CoV-2 is a coronavirus that emerged in China. The infection is now a pandemic that rapidly spread throughout the world and led to a global effort to contain it. Studies suggested that asymptomatic patients contributed 
to the extent of the spread of the disease. COVID-19 predominantly affects men and may present with multiple symptoms. COVID-19 worse outcomes are associated with increased age, comorbidities, complications, lymphocytopenia, and cytokine storm. Clinical features, radiological findings and laboratory results presented similarities in different populations, but case-fatality rates can be conflicting, exposing the necessity of studies according to each region.

Acknowledgments: The authors thank the Federal University of Ceará and the colleagues who contributed to the studies analyzed in this paper. This study was supported by the Brazilian Research Council - Conselho Nacional de Desenvolvimento Científico e Tecnológico, CNPq - and by Coordination of Improvement of Higher Level Personnel - Coordenação de Aperfeiçoamento de Pessoal de Nível Superior (CAPES).

Conflicts of interest: None.

Authors' contribution: Rangel AR contributed to the main idea and assisted in data collection, data analysis and manuscript preparation. Noronha LM and Chagas GCL assisted in data collection and preparation of the manuscript. Silva Júnior GB, Meneses GC, Pires Neto RDJ and Daher EF contributed to data analysis, preparation and revision of the manuscript. All authors approved the final version of the article.

\section{REFERENCES}

1. Guo Y, Cao Q, Hong Z, Tan Y, Chen S, Jin H, et al. The origin, transmission and clinical therapies on coronavirus disease 2019 (COVID-19) outbreak - an update on the status. Military Med Res. 2020;7(1):1-10. doi: 10.1186/s40779-020-00240-0.

2. Wu D, Wu T, Liu Q, Yang Z. The SARS-CoV-2 outbreak: What we know. Int J Infect Dis. 2020;94:44-8. doi: 10.1016/j. ijid.2020.03.004.

3. Wang N, Shang J, Jiang S, Du L. Subunit vaccines against emerging pathogenic human coronaviruses. Front Microbiol. 2020;11:298. doi: 10.3389/fmicb.2020.00298.

4. Xu H, Zhong L, Deng J, Peng J, Dan H, Zeng X, et al. High expression of ACE2 receptor of 2019-nCoV on the epithelial cells of oral mucosa. Int J Oral Sci. 2020;12(1):8. doi: 10.1038/s41368-020-0074-X.

5. World Health Organization. Coronavirus disease 2019 (COVID-19) situation report - 71. Genève; 2020 [cited 2020 April 01]. Available from: https://www.who.int/docs/ default-source/coronaviruse/situation-reports/20200331sitrep-71-covid-19.pdf?sfvrsn=4360e92b_8.

6. World Health Organization. COVID-19 Strategic Preparedness and Response Plan Operational Planning Guidelines to Support Country Preparedness and Response. Genève; 2020 [cited 23 April 2020]. Available from: https://www.who. int/docs/default-source/coronaviruse/covid-19-sprp-unctguidelines.pdf.

7. World Health Organization. Coronavirus disease 2019 (COVID-19) Situation Report - 51. Genève; 2020 [cited 27 April 2020]. Available from: https://www.who.int/docs/ default-source/coronaviruse/situation-reports/20200311sitrep-51-covid-19.pdf?sfvrsn=1ba62e57_10.

8. World Health Organization. WHO COVID-19 Dashboard. Genève; 2020 [cited 05 May 2020]. Covid19.who.int. 2020. Available from: https://covid19.who.int.

9. Han Y, Yang H. The transmission and diagnosis of 2019 novel coronavirus infection disease (COVID-19): a Chinese perspective. J Med Virol. 2020;92(6):639-44. doi: 10.1002/ jmv.25749.

10. Gandhi R, Lynch J, del Rio C. Mild or moderate Covid-19.
New Engl J Med. 2020;383(18):1757-66. doi: 10.1056/ NEJMcp2009249.

11. Wang W, Xu Y, Gao R, Lu R, Han K, Wu G, et al. Detection of SARS-CoV-2 in different types of clinical specimens. JAMA. 2020;323(18):1843-4. doi: 10.1001/jama.2020.3786.

12. Guan W, Ni Z, Hu Y, Liang W, Ou C, He J, et al. Clinical characteristics of coronavirus disease 2019 in China. New Engl J Med. 2020;382(18):1708-20. doi: 10.1056/ NEJMoa2002032.

13. Lippi G, Mattiuzzi C, Sanchis-Gomar F, Henry B. Clinical and demographic characteristics of patients dying from COVID-19 in Italy versus China. J Med Virol. 2020;92:175960. doi: 10.1002/jmv.25860.

14. Arons M, Hatfield K, Reddy S, Kimball A, James A, Jacobs $\mathrm{J}$, et al. Presymptomatic SARS-CoV-2 infections and transmission in a skilled nursing facility. New Engl Med. 2020;382:2081-90. doi: 10.1056/NEJMoa2008457.

15. Zou L, Ruan F, Huang M, Liang L, Huang H, Hong Z, et al. SARS-CoV-2 viral load in upper respiratory specimens of infected patients. New Engl J Med. 2020;382(12):1177-9. doi: 10.1056/NEJMc2001737.

16. Wei W, Li Z, Chiew C, Yong S, Toh M, Lee V. Presymptomatic transmission of SARS-CoV-2 - Singapore, January 23-March 16, 2020. MMWR Morb Mortal Wkly Rep. 2020;69:411-5. doi: 10.15585/mmwr.mm6914e1.

17. Tong Z, Tang A, Li K, Li P, Wang H, Yi J, et al. Potential presymptomatic transmission of SARS-CoV-2, Zhejiang Province, China, 2020. Emerg Infect Dis. 2020;26(5):1052-4. doi: 10.3201/eid2605.200198.

18. Qian G, Yang N, Ma A, Wang L, Li G, Chen X, et al. COVID-19 transmission within a family cluster by presymptomatic carriers in China. Clin Infect Dis. 2020;94:133-8. doi: 10.1016/j.ijid.2020.03.042.

19. World Health Organization. COVID-19 strategy update - 14 April 2020. Genève; 2020 [cited 2020 April 23]. Available from: https://www.who.int/publications-detail/covid-19strategy-update---14-april-2020.

20. Wang C, Pan R, Wan X, Tan Y, Xu L, Ho C, et al. Immediate psychological responses and associated factors during the 
initial stage of the 2019 Coronavirus disease (COVID-19) epidemic among the general population in China. Int $\mathrm{J}$ Environ Res Public Health. 2020;17(5):1729. doi: 10.3390/ ijerph17051729.

21. Lima C, Carvalho P, Lima I, Nunes J, Saraiva J, de Souza R, et al. The emotional impact of Coronavirus 2019-nCoV (new Coronavirus disease). Psychiatr Res. 2020;287:112915. doi: 10.1016/j.psychres.2020.112915.

22. Nicola M, Alsafi Z, Sohrabi C, Kerwan A, Al-Jabir A, Iosifidis $\mathrm{C}$, et al. The Socio-Economic Implications of the Coronavirus and COVID-19 Pandemic: a review. Int J Surg. 2020;78:185-93. doi: 10.1016/j.ijsu.2020.04.018.

23. Page K, Venkataramani M, Beyrer C, Polk S. Undocumented U.S. immigrants and Covid-19. New Engl J Med. 2020; 382(21):e62. doi: 10.1056/NEJMp2005953.

24. Liu J, Zheng X, Tong Q, Li W, Wang B, Sutter K, et al. Overlapping and discrete aspects of the pathology and pathogenesis of the emerging human pathogenic coronaviruses SARS-CoV, MERS-CoV, and 2019-nCoV. J Med Virol. 2020;92(5):491-4. doi: 10.1002/jmv.25709.

25. Lu R, Zhao X, Li J, Niu P, Yang B, Wu H, et al. Genomic characterisation and epidemiology of 2019 novel coronavirus: implications for virus origins and receptor binding. Lancet. 2020;395(10224):565-74. doi: 10.1016/ S0140-6736(20)30251-8.

26. Shereen M, Khan S, Kazmi A, Bashir N, Siddique R. COVID-19 infection: origin, transmission, and characteristics of human coronaviruses. J Adv Res. 2020;24:91-8. doi: 10.1016/j.jare.2020.03.005.

27. Wang L, Wang Y, Ye D, Liu Q. Review of the 2019 novel coronavirus (SARS-CoV-2) based on current evidence. Int J Antimicrob Agents. 2020;55(6):105948. doi: 10.1016/j. ijantimicag.2020.105948.

28. de Wit E, van Doremalen N, Falzarano D, Munster V. SARS and MERS: recent insights into emerging coronaviruses. Nature Rev Microbiol. 2016;14(8):523-34. doi: 10.1038/ nrmicro.2016.81.

29. Zou X, Chen K, Zou J, Han P, Hao J, Han Z. Single-cell RNAseq data analysis on the receptor ACE2 expression reveals the potential risk of different human organs vulnerable to 2019-nCoV infection. Front Med. 2020;14(2):185-92. doi: 10.1007/s11684-020-0754-0.

30. World Health Organization. Global surveillance for COVID-19 caused by human infection with COVID-19 virus: interim guidance. Genève; 20 March 2020 [cited 2020 April 23]. Available from: https://apps.who.int/iris/ handle/10665/331506.

31. World Health Organization. Laboratory testing for coronavirus disease 2019 (COVID-19)'in suspected human cases: interim guidance. Genève; 2 March 2020 [cited 2020 April 23]. Available from: https://apps.who.int/iris/ handle/10665/331329.
32. Centers for Disease Control and Prevention. Coronavirus Disease 2019 (COVID-19). US; 2020 [cited 2020 April 30]. Available from: https://www.cdc.gov/coronavirus/2019ncov/lab/guidelines-clinical-specimens.html.

33. Sharfstein J, Becker S, Mello M. Diagnostic Testing for the Novel Coronavirus. JAMA. 2020;323(15):1437. doi: 10.1001/jama.2020.3864.

34. Onder G, Rezza G, Brusaferro S. Case-fatality rate and characteristics of patients dying in relation to COVID-19 in Italy. JAMA. 2020;323(18):1775-6. doi: 10.1001/ jama.2020.4683.

35. Huang C, Wang Y, Li X, Ren L, Zhao J, Hu Y, et al. Clinical features of patients infected with 2019 novel coronavirus in Wuhan, China. Lancet. 2020;395(10223):497-506. doi:10.1016/S0140-6736(20)30183-5.

36. Yang X, Yu Y, Xu J, Shu H, Xia J, Liu H, et al. Clinical course and outcomes of critically ill patients with SARS-CoV-2 pneumonia in Wuhan, China: a single-centered, retrospective, observational study. Lancet Respir Med. 2020;8(5):475-81. doi:10.1016/S2213-2600(20)30079-5.

37. Chen N, Zhou M, Dong X, Qu J, Gong F, Han Y, et al. Epidemiological and clinical characteristics of 99 cases of 2019 novel coronavirus pneumonia in Wuhan, China: a descriptive study. Lancet. 2020;395(10223):507-13. doi:10.1016/S0140-6736(20)30211-7.

38. Wang D, Hu B, Hu C, Zhu F, Liu X, Zhang J, et al. Clinical characteristics of 138 hospitalized patients with 2019 novel Coronavirus-infected pneumonia in Wuhan, China. JAMA. 2020;323(11):1061-9. doi:10.1001/jama.2020.1585.

39. Grasselli G, Zangrillo A, Zanella A, Antonelli M, Cabrini L, Castelli A, et al. Baseline characteristics and outcomes of 1591 patients infected with SARS-CoV-2 admitted to ICUs of the Lombardy Region, Italy. JAMA. 2020;323(16):1574. doi: 10.1001/jama.2020.5394.

40. Bhatraju P, Ghassemieh B, Nichols M, Kim R, Jerome K, Nalla A, et al. Covid-19 in critically Ill patients in the Seattle Region — Case Series. New Engl J Med. 2020;382:2012-22. doi: 10.1056/NEJMoa2004500.

41. Arentz M, Yim E, Klaff L, Lokhandwala S, Riedo F, Chong $\mathrm{M}$, et al. Characteristics and outcomes of 21 critically Ill patients with COVID-19 in Washington State. JAMA. 2020;323(16):1612. doi: 10.1001/jama.2020.4326.

42. Bialek S, Boundy E, Bowen V, Chow N, Cohn A, Dowling $\mathrm{N}$, et al. Severe outcomes among patients with coronavirus disease 2019 (COVID-19) - United States, February 12-March 16, 2020. MMWR Morb Mortal Weekly Rep. 2020;69(12):343-6. doi:10.15585/mmwr.mm6912e2.

43. Chow N, Fleming-Dutra K, Gierke R, Hall A, Hughes M, Pilishvili T, et al. Preliminary estimates of the prevalence of selected underlying health conditions among patients with coronavirus disease 2019 - United States, February 12-March 28, 2020. MMWR Morb Mortal Weekly Rep. 2020;69(13):382-6. doi: 10.15585/mmwr.mm6913e2. 
44. Wang W, Tang J, Wei F. Updated understanding of the outbreak of 2019 novel coronavirus (2019-nCoV) in Wuhan, China. J Med Virol. 2020;92(4):441-7. doi: 10.26355/ eurrev_202004_21046.

45. Sommer P, Lukovic E, Fagley E, Long D, Sobol J, Heller $\mathrm{K}$, et al. Initial clinical impressions of the critical care of COVID-19 patients in Seattle, New York City, and
Chicago. Anesth Analg. 2020;131(1):55-60. doi: 10.1213/ ANE.0000000000004830.

46. Porcheddu R, et al. Similarity in case fatality rates (CFR) of COVID-19/SARS-COV-2 in Italy and China. J Infect Dev Countries. 2020;14(02):125-8. doi: 10.3855/jidc. 12600 .

Received: 2020 May 11

Accepted: 2021 April 07 